\title{
Potted Poinsettia Production: Irrigation and Water Quality 1
}

\section{C.D. Stanley and B.K. Harbaugh ${ }^{2}$}

There is no more essential component for the poinsettia production system than water, yet it is often less intensively managed than other production inputs. Perhaps the tendency to overlook the importance of water occurs because its use is linked so closely to other components of production which are intensively managed. Water management is a critical consideration for many aspects of production such as fertility control, media selection, and disease and insect control. In addition, because water conservation and protection have become important issues to society as a whole, poinsettia producers must consider management practices which minimize the impact that production has on the environment and water resources. This paper will discuss the uses of water in poinsettia production, the advantages and disadvantages of the use of different irrigation systems (management, maintenance, water conservation, and economics) available for poinsettia production, irrigation water requirements and scheduling, and plant and environmental water quality concerns.

\section{Uses of Water in Poinsettia Production}

While the most important consideration for use of water in poinsettia production is in providing for the physiological requirements for optimal growth and development, water can be used for meeting other essential needs as well. Plant establishment often requires special use of water, especially if plants are transplanted as unrooted cuttings. Much of this water is not used directly for growth by the plant, but is essential for keeping foliage cool and moist to prevent dessication and promote rooting. This operation is commonly achieved by use of a controlled mist system scheduled for short but frequent applications.

Irrigation water is increasingly used for fertilizer application in drip irrigation and subirrigation systems. If production occurs in a rain-sheltered environment, the application is closely linked to the water requirements for crop growth. However, in those production systems where rainfall is utilized, it is conceivable that fertilizer may need to be applied even when no water for growth is required. In this

1. This is document SL-212, a publication of the Soil and Water Science Department, Florida Cooperative Extension Service, Institute of Food and Agricultural Sciences, University of Florida, Gainesville, FL. Published January 2004. Please visit the EDIS Website at http://edis.ifas.ufl.edu.

2. C.D. Stanley, professor, Soil and Water Science Department and B.K. Harbaugh, professor, Environmental Horticulture Department, Gulf Coast Research and Education Center, Bradenton, FL. Florida Cooperative Extension Service, Institute of Food and Agricultural Sciences, University of Florida, Gainesville, FL 32611.

The Institute of Food and Agricultural Sciences (IFAS) is an Equal Opportunity Institution authorized to provide research, educational information and other services only to individuals and institutions that function with non-discrimination with respect to race, creed, color, religion, age, disability, sex, sexual orientation, marital status, national origin, political opinions or affiliations. U.S. Department of Agriculture, Cooperative Extension Service, University of Florida, IFAS, Florida A. \& M. University Cooperative Extension Program, and Boards of County Commissioners Cooperating. Larry Arrington, Dean 
case, the water used for fertilizer application would be essential for production to maintain the proper nutrient levels, although it would be applied in excess of the water needed for plant use.

\section{Irrigation Systems for Poinsettia Production}

Overhead, subirrigation, or microirrigation represent the three basic types of irrigation systems used for poinsettia production. There are many options in the design and equipment available for each of the three systems. Growers should be familiar with all aspects of each system before choosing an irrigation method. In making a decision, consider the water source, water quality, system costs (initial investment and maintenance), product advantages and disadvantages relative to that system, and design and engineering problems which may be affected by location, structure, and production practices. A limiting factor in any category may make an otherwise acceptable choice for an irrigation system impractical.

\section{Overhead Irrigation Systems}

Most overhead irrigation systems used in poinsettia production can be classified as either solid-set sprinkler or moving sprinkler systems. This section will not deal with overhead microirrigation systems, but that will be covered later. The most basic form of an overhead system is hand watering. However, this system is labor intensive and water applied in this way varies in uniformity with the operator. Because labor requirements are high, only small operations generally employ this type of irrigation.

The solid set systems can use rotary sprinkler heads or stationary spray heads. Water may be applied above or below the foliage depending on crop and system design. The application rate from sprinklers and spray heads decreases with distance from the emitter. Therefore, when irrigating several pots with the same sprinkler, overlapping patterns are necessary to maintain a uniform distribution of water. These devices are generally spaced at 50 percent of their respective diameters of throw so that water from one emitter reaches the base of the adjacent emitters.
Rotary sprinkler heads vary in design with respect to the drive mechanism, operating pressure requirements, discharge flow rate, and water application characteristics such as rate, droplet size, and water distribution. Rotation is achieved by either an impact hammer mechanism or a system of water driven gears. Operating pressure can range from 25 pounds per square inch (psi) to $100 \mathrm{psi}$. As fuel costs continue to increase the higher pressure systems become less desirable because the energy requirements of these systems are greater than those for the lower pressure systems. Discharge rates can range from 1 gallon per minute (gpm) for small sprinklers to over $100 \mathrm{gpm}$ for the larger sprinklers. When arranged as a system, these units can be selected to provide application rates from 0.1 inch per hour to 2.0 inches per hour to a given area.

Stationary spray heads do not rotate but do have many of the same characteristics as rotary sprinklers. One advantage includes the ability to select a wide range of application patterns. This enables customizing of a system to irregular layouts. Operating pressures vary but are generally less than $50 \mathrm{psi}$ and are commonly 15 to $35 \mathrm{psi}$, and therefore have low to moderate energy requirements. Small spray heads may have discharge rates of $0.25 \mathrm{gpm}$ for $1 / 4$ circle models to 3.0 gpm for larger full circle models. Application rates may range from 0.5 to 5.0 inches per hour depending on design.

Spray boom or trolley systems generally use spray nozzles to distribute the water. These systems can be used in greenhouses or other structures and move laterally down the length of the growing area. Depth of water applied is controlled by adjusting the linear speed of the spray boom. The spray nozzles used with these systems provide small droplets. This small droplet size is suitable for cutting or transplant production where larger drops could be damaging.

Application efficiency will depend on the beneficial area of coverage, the ability for water to enter the containers or root zone, evaporation losses, and wind drift. These factors will be different for poinsettia container operations than for field operations growing other crops. The container surface area may only account for 20 to $40 \%$ of the total application area. In addition, foliage may 
restrict water from entering the containers, thus further reducing application efficiency. Water evaporates as it is transported from the emitter to the crop. These evaporation levels may be as high as $10 \%$ of the water applied on a hot dry afternoon. Wind also reduces efficiency by distorting distribution patterns and transporting water to areas outside of the zone to be irrigated.

Some of these inefficiencies can be alleviated by installing a runoff catchment system where containers are placed on a slightly sloped plastic or impermeable surface allowing the collection of irrigation and rainfall runoff for reuse. However, pathogens and/or chemicals may be recirculated through this system and may be damaging if not monitored periodically. In many cases, water treatment may alleviate any problems.

Chemigation (applying chemicals including fertilizer through the irrigation system) is possible with sprinkler and spray systems. However, the application efficiency of chemicals is limited to the application efficiency of the water distribution system. Most states have regulations concerning chemical injection into irrigation systems, and proper backflow prevention must be used or other precautions must be must followed in order to comply.

Foliar application of water increases the incidence potential of water-related foliar diseases. Wet foliage may also hamper certain production practices or wash off certain beneficial chemicals. These items need to be considered in the irrigation scheduling process.

An additional advantage of overhead systems is use for crop cooling during hot periods. Sometimes sprinkler and spray systems are solely installed for these applications while another system may be used to provide the water needs of the crop. They are also adaptable to automation, which can reduce labor costs and help with system management.

\section{Ebb and Flow (Gravity-Flow) Subirrigation Systems}

This category of irrigation systems will include contained subirrigation systems. Another type of subirrigation system known as the capillary mat system will be discussed in the next section under microirrigation systems. Gravity flow subirrigation (ebb and flow) systems rely on gravity to distribute water evenly throughout greenhouse with specifically designed benches, troughs or floors. Therefore, system operating pressures are low, resulting in relatively low pumping power requirements.

For poinsettia production using an ebb and flow system, pots are placed in containment areas within which water tables (1 to 1.5 inches) can be established. Water then moves upward into the pots by capillary action and the water is removed after an adequate amount of time for pot water uptake. This method of irrigation has low application efficiencies and is not water-conservative if the drained water is not recovered and used for subsequent irrigations. Additional management techniques are required when water is recovered because salinity levels may increase in recycled water due to leaching of fertilizer salts, and pathogens may be spread by utilizing recycled water without disinfection.

Chemigation is not recommended with either of these systems. These systems require large volumes of water and will therefore require comparable levels of chemicals. Therefore the economics of such an application would be difficult to justify. Furthermore the chemical application efficiency can never be greater than the water application efficiency, which is low with these systems.

\section{Microirrigation Systems}

Microirrigation systems include use of line-source lateral drip tubes, microsprayers, microsprinklers, spaghetti tubes, capillary mat, and numerous other emitter devices and systems. In general, these systems have the characteristics of low water application rate and low operating pressure requirements. Volume of water applied is controlled by the period of operation as well as the emitter 
characteristics. These systems apply water at low rates to localized zones and allow precise and controlled irrigation applications. Therefore low volume applications can be achieved with proper management. Poor management can result in high volume applications, reducing system efficiency.

Several systems are available for use with potted poinsettia production. These systems include microsprayers, spaghetti (individual pot) tubes, and line source drip tubes used with a capillary mat. Required operating pressures will range from 5 psi to 30 psi. Therefore pumping power requirements are generally low.

Microsprayers apply water as small streams or sprays and are primarily used in potted plant production. These systems may be designed to apply water to the foliage or just to the pots. If crop cooling or foliar chemigation is desired, the former choice should be used. However, if chemical precipitation is a problem, the latter choice may be necessary to maintain clean foliage. Emitter discharge rates can vary from 5 to 50 gallons per hour (gph) with diameters of coverage ranging from 4 to 25 feet. This allows precise water control in relatively small areas.

Spaghetti tube systems also apply water directly to the individual containers. The inside diameter of spaghetti tubing is small ( 0.036 inch to 0.076 inch) which provides a restricted flow path for water control. The spaghetti tubing is cut to the desired length and then one end of the tubing is weighted or attached to a small stake and placed in the container to be irrigated. The other end is inserted into the lateral supply tube which conveys water from the pump or water supply system. Spaghetti tube systems are designed to deliver water and chemicals directly to the plant root zone. This eliminates irrigation of non-production areas and increases application efficiency. A uniformly mixed, well-graded potting media should be used. Use of these systems may require initial overhead or hand watering to establish a wet profile in the potting media.

Capillary mat systems require use of line-source drip tubes to operate. These drip tubes apply water to the capillary mat which distributes the water to the pots accomplished by upward capillary movement of water from the mat into the potting media. Since an initially wet profile is necessary to establish capillarity, overhead watering is necessary while the mat is initially wetted to establish capillarity between the mat and pot.

Chemigation is not recommended for use with capillary mat systems. These systems do not apply water directly to the plants or pots, therefore control of chemical application rates or amounts becomes difficult. The use of controlled release fertilizers is recommended for nutritional requirements.

Maintenance of microirrigation systems is more involved than previously discussed systems. The small orifices and openings of these systems can clog with small particles or growths. Therefore water treatment or amendment and filtration is generally necessary as well as periodic cleaning of the system.

Because water is applied so precisely, the systems can be managed for optimal water conservation. As with the sprinkler and spray systems, water should be applied to remain within the active root zone of the crop. Excessive water applications are not only wasteful, but can leach beneficial nutrients out of the root zone as well.

\section{Irrigation Water Requirements and Scheduling}

Poinsettias require a great deal of attention to watering practices. Underwatering poinsettias results in stunted plants with small leaves and bracts, and severe wilting may result in loss of part or all of the lower leaves. On the other hand, overwatering may incite root or foliar diseases, leaf chlorosis, or delay bract coloration.

The amount of water to apply and the frequency of application are critical concerns of all poinsettia growers, yet a single or simple rule cannot be given to resolve these concerns. Factors influencing irrigation rates and frequency alone and in combination include plant size and vigor, potting soil, climatic and environmental conditions, production structure or crop management and type of irrigation system. For example, with a fan- and pad-cooled glass greenhouse, 50\% shade, and south Florida production, a newly established poinsettia in a 
$15 \mathrm{~cm}$ (6 inch) pot may have an evapotranspiration rate (ET, the amount of water actually evaporating from the soil or lost through plant transpiration) of 75 to $100 \mathrm{ml}$ (2.5 to $3.3 \mathrm{oz})$ per day as compared to a mature plant with an ET rate of 150 to $200 \mathrm{ml}$ (5 to $6.5 \mathrm{oz}$ ) per day. Poinsettias grown under polypropylene shade structures produced at the same time may have ET rates of 100 to $130 \mathrm{ml}$ (3.2 to 4.2 oz) per pot per day initially, and 200 to $260 \mathrm{ml}$ (6.5 to $8.5 \mathrm{oz}$ ) per pot per day for mature plants. These values could easily be 30 to $50 \%$ greater on high evaporative demand days (hot, windy and low humidity) or in northern Florida with forced air heating and lower humidity. These values accurately define the water needs of a poinsettia, but the exact amount of irrigation water required will be determined by the irrigation system and its application efficiency. Spaghetti tube systems approach 90 to $100 \%$ efficiency, but an overhead system may require 18 to 20 times the ET rate to supply the ET rate to each pot. Thus, the water requirements of poinsettias may vary from $100 \mathrm{ml}$ (2.5 oz) per pot per day for young plants in a south Florida greenhouse with a spaghetti tube system to $8000 \mathrm{ml}$ (2.1 gallons) per pot per day for a mature plant in a saran house on a windy day irrigated with an overhead system. The additive effects of plant size, growing environment, and irrigation system, plus the need for flexibility to change frequency of application for changes in crop size or climatic conditions, will dictate the success or failure of the growers' watering practices. Poinsettias will tolerate a slight wilt with little effect on growth but leaves will abscise or drop from the plant following severe wilt. Leaf enlargement will be restricted slightly from moderate wilt during the first stages of floral initiation (September to October) but overall plant quality will not be affected since plant height and bract size remain similar to well watered plants. Plants are more sensitive to wilt during the latter stages of the crop cycle and they should be watered no later than the first sign of wilt (leaf droop) during the last 3 to 4 weeks of production since further stress may reduce bract size and result in leaf drop. Watering plants in a manner to avoid any wilt or temporary water stress will result in taller plants, so compromise and good judgement by the grower is necessary to prevent leaf loss and luxuriant or succulent growth.
The amount of water applied at each irrigation event must be enough to wet the soil thoroughly, but not be excessive to the degree that nutrients are moved out of the pot. When fertilizer is applied in the irrigation water it is essential that over-application does not occur, since nutrient loss occurs with water loss. If fertilizer was applied in a dry form in each pot, again, over-irrigation will cause some loss of nutrients to occur. It is clear that nutrient management and water management are so closely tied that they can't be separated. The water holding capacity of the potting media and the degree to which the media is allowed to dry must be considered when determining the maximum amount of water that can be applied at any one irrigation cycle.

Most growers use a combination of observation and routine to determine when and to what extent to irrigate. From past experiences and observations, they determine the length of time before the pot media dries and establish routine applications. Automated equipment, such as a tensiometer or a potted plant on a balance which trips a solenoid valve, have been used successfully by some growers, but these systems require some experience and must be monitored to ensure success. With more sophisticated sensors being developed and use of computers, the future of automated irrigation may be a computer program that utilizes plant production input such as age of crop, pot size and spacing with sensor readings of light, temperature, and humidity to achieve the necessary flexibility of irrigating as conditions change. For example, a study (Stanley and Harbaugh, 1989) to determine the effect of plant size (height and width) and pan evaporation yielded a simple equation to estimate plant water requirements (on a per pot basis). The equation was: $\mathrm{ET}=-118.0+$ $2.3(\mathrm{HT})+1.8(\mathrm{WT})+58.2(\mathrm{EVAP})$, where: $\mathrm{ET}=$ total water use $(\mathrm{ml}) ; \mathrm{HT}=$ plant canopy height $(\mathrm{cm})$; $\mathrm{WT}=$ plant canopy width $(\mathrm{cm})$; and, $\mathrm{EVAP}=$ daily pan evaporation $(\mathrm{mm})$. The user simply inputs a representative value for plant height, width, and daily pan evaporation to get an estimate of daily water requirement. Tools such as these can help schedule irrigations and be useful in planning for future water needs. 


\section{Water Quality}

Water quality is very important to poinsettia production for two primary reasons: how it affects plant growth and how it affects irrigation system maintenance. The source of the water determines to a great degree which problems could occur. Well water is generally used as the source of irrigation water, but municipal or surface (lake, river, shallow wells) water is occasionally used. Whatever the source, the quality of the water must be determined before an irrigation system is selected. Growers should understand or become aware of the effects of water quality on poinsettia production practices as well as its influence on design and maintenance of the system.

The major problems with well water are high total soluble salts (TSS or salinity), iron, and hydrogen sulfide. Production of poinsettias with water containing over 1400 ppm TSS usually results in crop failure and is not recommended, unless it is diluted with another water source. Water high in TSS ( 800 to $1200 \mathrm{ppm}$ ) may be used with proper management, which requires that the soil must be leached weekly and maintained moist so the salts in the soil solution will not become concentrated and kill roots. Water with $700 \mathrm{ppm}$ TSS or less is considered safe and requires no special management practices.

While TSS is a major consideration, the grower cannot overlook specific dissolved minerals or elements comprising the TSS. Elements, such as boron, copper and fluoride, at concentrations greater than $0.5-1 \mathrm{ppm}$ are generally toxic. High levels of calcium, sodium, bicarbonates and sulfates may clog emitters directly or indirectly by precipitating injected fertilizer. While specific problematic levels of these ions are difficult to define due to complicating factors such as $\mathrm{pH}$ and/or sulfides affecting solubilities, levels above $150 \mathrm{ppm}$ should warrant special attention to prevent clogging or precipitation of fertilizer from formation of insoluble compounds. Growers can use a simple test in addition to water analyses to estimate potential precipitation problems. Fill a clean clear jar with irrigation water and add ammonium hydroxide to raise the $\mathrm{pH}$ to around 9. Let the solution react for 12 hours and then observe for precipitates in the bottom of the jar. Gently stir to determine if particles will be suspended or have coated the bottom of the jar. The same procedure can be used for irrigation water after fertilizer has been injected.

Sodium can often reach 60 to $80 \%$ of the total soluble salts when salt water intrusion into wells has occurred. High sodium concentrations are toxic to plants and interfere with calcium, magnesium and potassium uptake. The Sodium Absorption Ratio [SAR $=$ milliequivalents/liter NA $\quad(\mathrm{Ca}+\mathrm{Mg}) / 2]$ is often used as an indicator of water quality with values greater than 9 indicating unsuitable, 3 to 9 acceptable and 1 to 3 good.

Iron $(\mathrm{Fe}>0.3 \mathrm{ppm})$ or sulfur $\left(\mathrm{H}_{2} \mathrm{~S}>0.5 \mathrm{ppm}\right)$ in irrigation water can be a limiting factor for use in low volume systems as bacteria form a reddish iron sludge or a gelatinous sulfur slime clogging pipes or emitters. Chlorine can be injected into the irrigation system to control bacteria and has been used successfully by many growers to alleviate this water quality problem. The University of Florida Cooperative Extension Service has publications (http://edis.ifas.ufl.edu/) available with specific detailed information on chlorine treatment rates and commercial irrigation companies can also provide details on injection equipment.

Irrigation water should have a $\mathrm{pH}$ of 6.5 to 7.5 to avoid precipitation of fertilizer in irrigation systems and to prevent changes in the soil $\mathrm{pH}$ or balance of available nutrients. The $\mathrm{pH}$ of irrigation water can be adjusted by injecting acid or base chemicals, using acid or base fertilizer solutions, or amending the soil prior to use to compensate for the effect of the applied water during the cropping periods.

Alkalinity or hardness is a measure of water's ability to neutralize acids while the $\mathrm{pH}$ of the water will indicate the actual acidic or basic nature of the water. Thus it is important to know not only the $\mathrm{pH}$ of your water but also the alkalinity in order to determine the influence irrigation water will have on changing media $\mathrm{pH}$ during the crop cycle. Alkalinity is generally presented as ppm hardness or as milliequivalents/liter calcium carbonate (meq $\mathrm{CaCO}_{3}$ ). Alkalinity levels of 2 to 4 meq $\mathrm{CaCO}_{3}(100$ to $200 \mathrm{ppm}$ ) are considered normal. Lower levels may result in undesirable medium $\mathrm{pH}$ depression 
during the crop cycle and higher levels may result in media $\mathrm{pH}$ levels above desired levels (> pH 7).

Tannins, phenolics, and humic acids at concentrations greater than $2 \mathrm{ppm}$, suspended solids (organic matter) greater than $100 \mathrm{ppm}$, and disease organisms are additional problems encountered with surface water. Special filtration systems and chlorination treatments may be necessary before surface water can be used.

Municipal water sources are generally suitable for irrigation but the cost is impractical. Some growers use municipal water to dilute saline well water or to leach media where salts have accumulated. Growers with low water usage systems (drip or capillary mat) may be able to justify municipal sources when well or surface waters are so poor in quality that filtration and treatment costs are similar to municipal charges. If municipal water is used, a water analysis is necessary as $\mathrm{pH}$, dissolved minerals or specific elements need to be considered.

\section{Water Quality Protection}

It is important to be aware that water quality problems can occur from water containing applied agrichemicals leaving the production area (surface or subsurface) as a result of poor irrigation management. Water is such an important component of the poinsettia production systems that this resource quality must be conserved and protected from degradation as much as possible. In those areas where water availability has become restricted due to increased demand by other users, or where vulnerability of water resources to be contaminated by runoff, strong consideration must be given to use of a water conserving irrigation system such as drip or capillary mat, or subirrigation where runoff water is reused. Water conservation benefits the system both from conserving the resource and reducing the runoff losses which can contain agrichemicals used in the production system.

\section{Related References}

Clark, G. A., D.Z. Haman and F.S. Zazueta. 1998. Injection of Chemicals Into Irrigation Systems: Rates, Volumes, and Injection Periods. http://edis.ifas.ufl.edu/AE116
Clark, G. A. and Allen G. Smajstrla. 1998. Treating Irrigation Systems with Chlorine. http://edis.ifas.ufl.edu/AE080

Haman, Dorota, Z., Allen G. Smajstrla and Fedro S. Zazueta. 1994. Chemical Injection Methods for Irrigation. http://edis.ifas.ufl.edu/WI004

Smajstrla, A. G., F. S. Zazueta, G. A. Clark, and D. J. Pitts. 2000. Irrigation Scheduling with Evaporation Pans. http://edis.ifas.ufl.edu/AE118

Stanley, C. D. and B. K. Harbaugh. 1987. Poinsettia irrigation based on evaporative demand and plant growth characteristics. HortScience 24:937-939. 